\title{
Correlation of methylation status in MTHFR promoter region with recurrent pregnancy loss
}

\author{
Mai Mahmoud Shaker ${ }^{1 *}$, Taghreed Abdelmoniem shalabi ${ }^{1}$ and Khalda said $\mathrm{Amr}^{2}$
}

\begin{abstract}
Background: DNA methylation is an epigenetic process for modifying transcription factors in various genes. Methylenetetrahydrofolate reductase (MTHFR) stimulates synthesis of methyl radical in the homocysteine cycle and delivers methyl groups needed in DNA methylation. Furthermore, numerous studies have linked gene polymorphisms of this enzyme with a larger risk of recurrent pregnancy loss (RPL), yet scarce information is available concerning the association between epigenetic deviations in this gene and RPL. Hypermethylation at precise DNA sequences can function as biomarkers for a diversity of diseases. We aimed by this study to evaluate the methylation status of the promoter region of MTHFR gene in women with RPL compared to healthy fertile women. It is a case-control study. Hundred RPL patients and hundred healthy fertile women with no history of RPL as controls were recruited. MTHFR C677T was assessed by polymerase chain reaction-restriction fragment length polymorphism (RFLP). Quantitative evaluation of DNA methylation was performed by high-resolution melt analysis by real-time $P C R$.
\end{abstract}

Results: The median of percentage of MTHFR promoter methylation in RPL cases was 6.45 [0.74-100] vs. controls was 4.50 [0.60-91.7], $P$ value $<0.001$. In the case group, 57 hypermethylated and 43 normo-methylated among RPL patients vs. 40 hypermethylated and 60 normo-methylated among controls, $P<0.005$. Frequency of $T$ allele in C677T MTHFR gene among RPL patients was $29 \%$ vs. $23 \%$ among the control group; $C$ allele vs. T allele: odds ratio $(\mathrm{OR})=1.367$ (95\% confidence interval (Cl) $0.725-2.581$ ).

Conclusion: Findings suggested a significant association between hypermethylation of the MTHFR promoter region in RPL patients compared to healthy fertile women.

Keywords: Pregnancy loss, Methylation, Methylenetetrahydrofolate reductase, Polymorphism, Thrombophilia

\section{Background}

RPL is defined as more than two to three consecutive pregnancy losses earlier to the 20th week of gestation [1]. Around $1-5 \%$ of married couples suffer from this stressful event worldwide. Full-term pregnancies embraces mechanisms that avoid expulsion of fetus semi-allograft as well as sharp regulation measures for fluctuations in maternal

\footnotetext{
* Correspondence: maishaker777@gmail.com

'Prenatal and Fetal Medicine Department, Human Genetics and Genome Research Division, National Research Centre, 33 El Buhooth St, Dokki, Cairo, Egypt

Full list of author information is available at the end of the article
}

environment in response to any changes required during fetal growth. Epigenetic mechanism involving DNA methylation has a great impact on monitoring the evolution processes of the trophoblastic cell lines $[2,3]$. Changes in carbon metabolic pathway which is the main provider of one carbon units are expected to affect methylation arrangements [4].

In early gestation weeks during initial steps of fetal growth formation, DNA methylation of fetal germ cells is needed for regular spermatogenesis and fetal growth after conception [5]. The keys in epigenetic mechanisms are DNA methylation, post-translational histone modifications,
Springer Open (c) The Author(s). 2021 Open Access This article is licensed under a Creative Commons Attribution 4.0 International License, which permits use, sharing, adaptation, distribution and reproduction in any medium or format, as long as you give appropriate credit to the original author(s) and the source, provide a link to the Creative Commons licence, and indicate if changes were made. The images or other third party material in this article are included in the article's Creative Commons licence, unless indicated otherwise in a credit line to the material. If material is not included in the article's Creative Commons licence and your intended use is not permitted by statutory regulation or exceeds the permitted use, you will need to obtain permission directly from the copyright holder. To view a copy of this licence, visit http://creativecommons.org/licenses/by/4.0/. 
chromatin remodeling, and regulation of small noncoding RNA [6]. Still DNA methylation is the utmost commonly assessed epigenetic modification in context of RPL. It represents the methylation of cytosines at CpG (cytosine-phosphate-guanine) dinucleotide. DNA methylation regularly happens at $\mathrm{CpG}$ islands in promoter region of the genes to adjust gene expression, Though hypermethylation of DNA in $5^{\prime}$-CpG-3' islands is related with gene suppression, hypomethylation among those regions is related to transcriptional activation [7]. Lucas et al. [8] investigated how alteration in methylation at the level of stem cell methylation can be responsible for active variations in stem cell populations which leads to abnormal plasticity of the uterine endometrium and consequently pregnancy loss. Pliushch et al. [9] stated that epimutations that lead to unsuitable methylation and expression patterns of genes may add to increased incidence of pregnancy failures.

One of the common thrombophilia genes is MTHFR gene. It is essential in making methyl groups needed for DNA methylation, repair, and synthesis. During gestation period, females experience lots of physiological changes; these changes influenced by methylation pattern of some genes. MTHFR have a critical role during gestation period due to its enrollment in some thrombotic events and methylation process. Hypermethylation of the promoter region of MTHFR gene decreases gene expression. Consequently, it lowers the accessibility of methyl groups needed for entire DNA methylation [10]. DNA methylation leads to the addition of a methyl group at $5^{\prime}$ carbon of cytosine which can bring changes in DNA structure as well as altering the set patterns of gene expression. Moreover, MTHFR C677T polymorphism may lead to decrease in enzymatic activity hindering transmethylation cycle which in return diminish the availability of free methyl groups and slowing down DNA methylation process [11]. We believe that in cases of RPL especially (unexplained RPL), early finding of new prognostic marker would be of great help to obstetricians for early detection and management of RPL patients. We aimed by this study to evaluate the methylation status of the promoter region of MTHFR gene in RPL patients compared to healthy fertile women.

\section{Methods}

\section{Recruitment of participants}

This is a case-control study. Participants included in the two studied groups had a comparable age $25.7 \pm 5.1$ years vs. 26.2 \pm 4.7 years, $p=0.495$ and body mass index (BMI) $26.4 \pm 2.5$ vs. $27.0 \pm 2.7, p=0.140$. Participants were referred to our Recurrent Pregnancy Loss clinic at our institute, from the period of September 2018 to March 2020. Our inclusion criteria for the case group included hundred RPL patients who had passed through at least two to three consecutive pregnancy losses with the same spouse. None of the participants were smokers or alcoholic. Patients with recurrent pregnancy loss risk factors like anatomic malformations, karyotype abnormality, disturbance in hormonal levels mainly (thyroid profile and progesterone), immunological abnormalities (anticardiolipin antibodies, anti- $\beta 2$ glycoprotein 1 antibody, antithyroglobulin antibody and antinuclear antibody), history of thrombotic events, inherited thrombophilia mutations, deficiency for protein $\mathrm{c}$ and $\mathrm{s}$, and infections (cytomegalovirus, rubella, and chlamydia trachomatis) were excluded. Hundred healthy fertile women were recruited in the control group who had full-term pregnancy, gave birth to healthy children, and have not experienced any form of pregnancy loss or any pregnancy-related complications. All participants signed a written informed consent before sampling and the study was accepted by the Medical Ethical Committee of NRC.

\section{Extraction of genomic DNA}

After blood sampling, $2 \mathrm{~mL}$ of whole blood was collected into Ethylenediaminetetraacetic acid (EDTA)-containing tubes for genomic DNA extraction. Genomic DNA was isolated from whole blood using salting out technique [12]. DNA was eluted in $100 \mu \mathrm{l}$ of distilled water and finally stored at $-20^{\circ} \mathrm{C}$ till analysis.

\section{Genotyping of C677T polymorphism in MTFHR gene}

Genotyping for C677T SNP was analyzed using PCR and restriction fragment length polymorphism analysis (RFLP). The sequence of primers used was as follows: forward primer 5' -TGTGGTCTCTTCATCCCTCGC-3' and reverse primer $5^{\prime}$-CCTTTTGGTGATGCTTGT TGGC-3' [13]. PCR thermal condition was as follows: initial denaturation for $5 \mathrm{~min}$ at $95{ }^{\circ} \mathrm{C}, 30$ cycles of $30 \mathrm{~s}$ at $94{ }^{\circ} \mathrm{C}$, annealing at $60^{\circ} \mathrm{C}$ for $30 \mathrm{~s}$ and extension for $30 \mathrm{~s}$ at $72^{\circ} \mathrm{C}$ and a final extension for $10 \mathrm{~min}$ at $72^{\circ} \mathrm{C}$. Twomicroliter PCR yields were loaded in 3\% agarose gel to check for successful amplification, band size (513 bp). Electrophoresis was done. All PCR products were allied against a 100bp DNA Ladder (Fermentas, Germany).

Fast Digest Hinfl (Thermo Scientific; Thermo Fisher Scientific) was used for the RFLP step. Final mixture reaction of total volume of $15 \mu \mathrm{l}$ was prepared with $1 \mu \mathrm{l}$ of HinfI enzyme, $1.5 \mu \mathrm{l}$ Buffer with a concentration of (10x), $2.5 \mu \mathrm{l}$ of sterile $\mathrm{H}_{2} \mathrm{O}$, and 10ng of PCR final product. The reaction was then incubated at $37^{\circ} \mathrm{C}$ for $35 \mathrm{~min}$ in a thermal cycler then followed by inactivation step by heating at $80^{\circ} \mathrm{C}$ for $25 \mathrm{~min}$. If MTHFR C677T polymorphism is found, the exchange of $\mathrm{C}$ with $\mathrm{T}$ generates a restriction site for Hinf I and the PCR product of 513 bp is cut in two pieces, one of $146 \mathrm{bp}$ and the other of 367 bp [13] as shown in Fig. 1. 


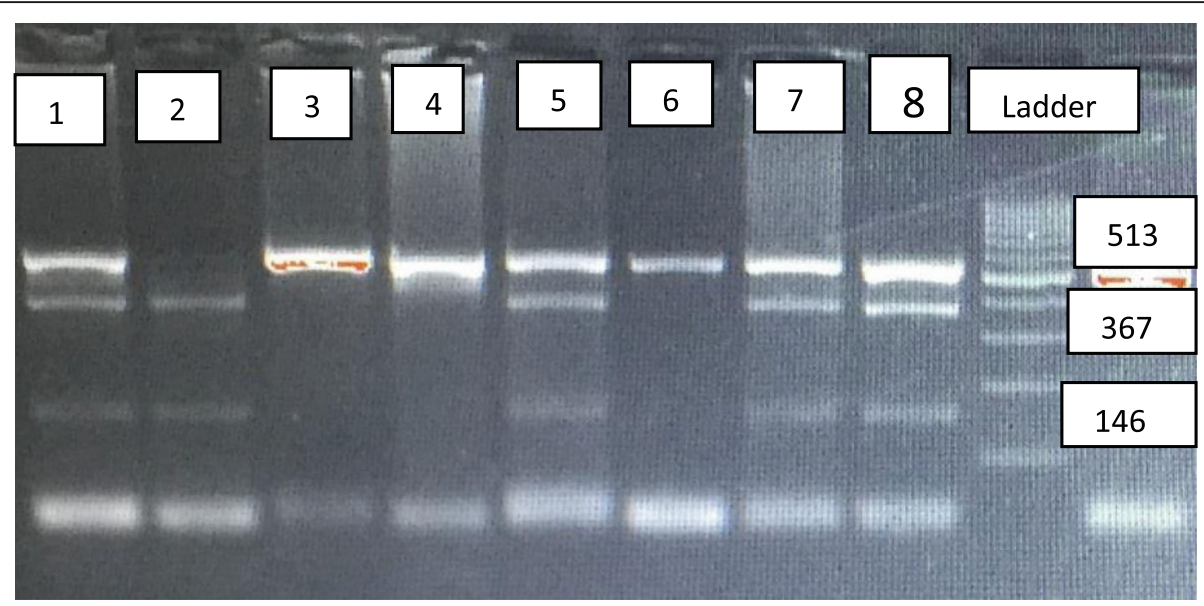

Fig. 1 Digested pcr products using Hinf 1 enzyme for C667T polymorphism. 3\% agrose gel showing digested pcr products: (a) lanes 1, 5, 7, and 8 showing 513,367 and 146 bp bands (CT genotype); (b) lane (2) showing 367 and 146 bp bands (TT genotype); (c) lanes 3, 4, and 6 showing 513 bp band (CC genotype); and (d) ladder, 100 base pair (bp) molecular marker

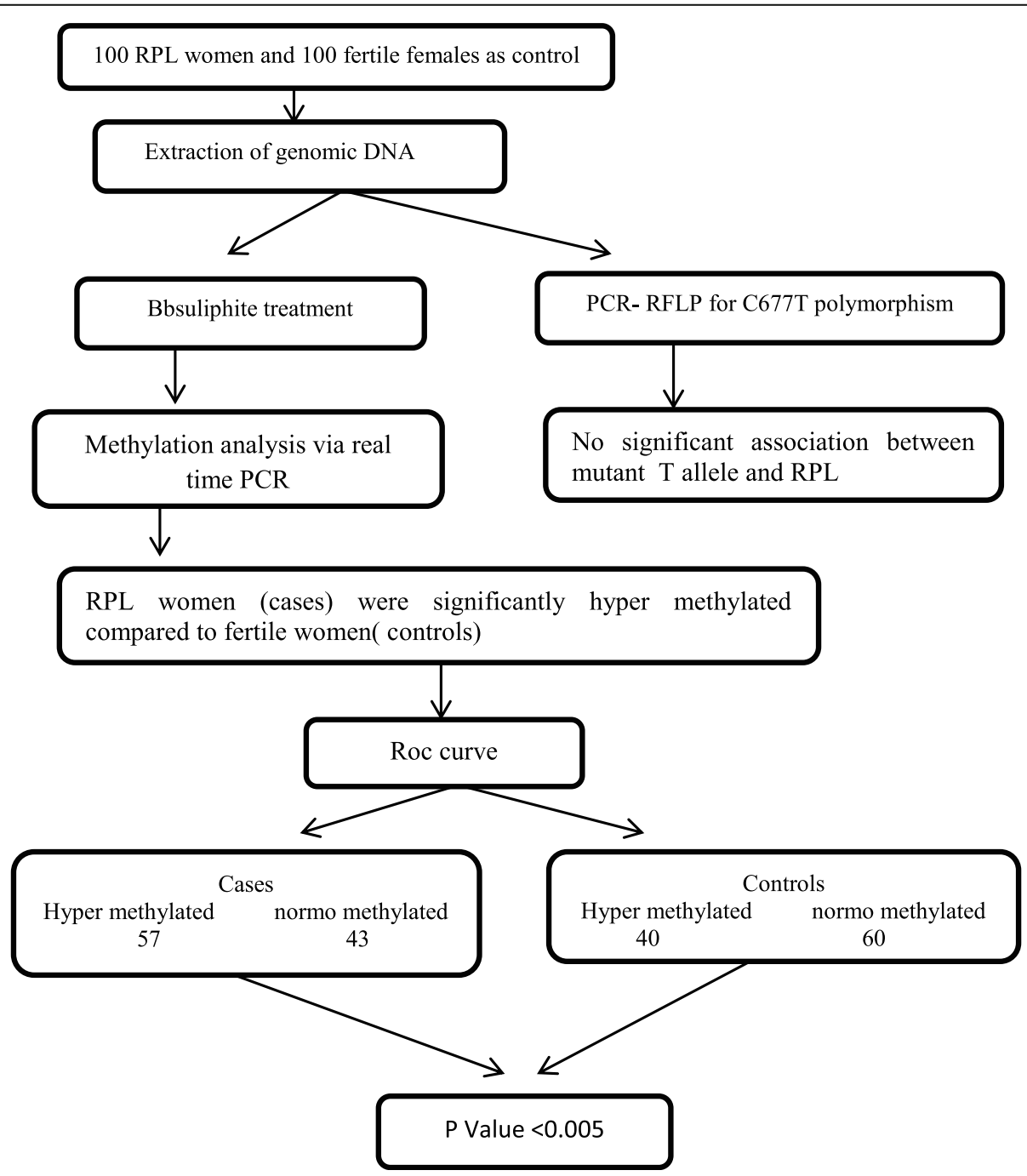

Fig. 2 Study plan and outcome 


\section{Bisulphite DNA conversion}

Five hundred nanograms of purified genomic DNA was bisulfite-treated using the EZ DNA Methylation ${ }^{\mathrm{T}}$ Kit (Cat No. D5006, Zymo Research, CA, USA). The bisulfite-modified DNA was used for gene-specific methylation analysis of Promoter region of MTHFR gene. In each run, positive control (100\% methylated) and negative control ( $0 \%$ methylated) were used using Methylated and Unmethylated DNA CpG Genome (Chemicon International Inc.) as a reference.

\section{Real-time methylation quantification analysis}

Real-time PCR reactions was performed following this amplification protocol: $15 \mathrm{~min}$ on $95^{\circ} \mathrm{C}, 52$ cycles of $32 \mathrm{~s}$ on $95^{\circ} \mathrm{C}, 30 \mathrm{~s}$ at $57^{\circ} \mathrm{C}, 30 \mathrm{~s}$ at $72^{\circ} \mathrm{C}$ with a last extension lead of $35 \mathrm{~min}$ at $72{ }^{\circ} \mathrm{C}$. The following are the methylated primers used: frontward 5-TTAGGAGTGG TTGTAGACGGGT-3 and reverse 5-GAATAACTCA AAACGCTCGAC-3. The unmethylated primers were: frontward 5-TTAGGAGTGGTTGTAGATGGGT-3 and reverse 5-CCCAAATAACTCAAAACACTCAAC-3. The primers were designed precisely for methylated and unmethylated regions in the first CpG Island at MTHFR coding region with comparable annealing temperatures. To assess the percentage of methylation status, every single sample was normalized to a non-CpG promoter region of the MTHFR gene. $2 \Delta \triangle \mathrm{Ct}$ equation was used to resolute the relative degree of methylation [14]. The overall study plan and results outcome is summarized in brief in Fig. 2.

\section{Statistical analysis}

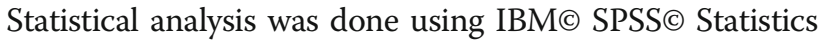
version 22 (IBM@ Corp., Armonk, NY, USA). Numerical data were expressed as mean and standard deviation or median and range as appropriate. Qualitative data were expressed as frequency and percentage. Fisher's exact test was used to examine the relation between qualitative variables. For quantitative data, comparison between two groups was done using independent sample $t$-test. Logistic regression was used to assess the risk of genotypes and alleles. The odds ratio (OR) with it 95\% confidence interval (CI) were used for risk estimation. A receiver operating characteristic (Roc curve) was done to obtain a cuff off value for the methylation percentage in order to categorize participants to either normo- or hypermethylated and $p$ value was obtained using chi-square test. A $p$ value $<0.05$ was considered significant (Fig. 3).

\section{Results}

The descriptive parameters (age, BMI, and consanguinity rate) between the two studied groups showed no

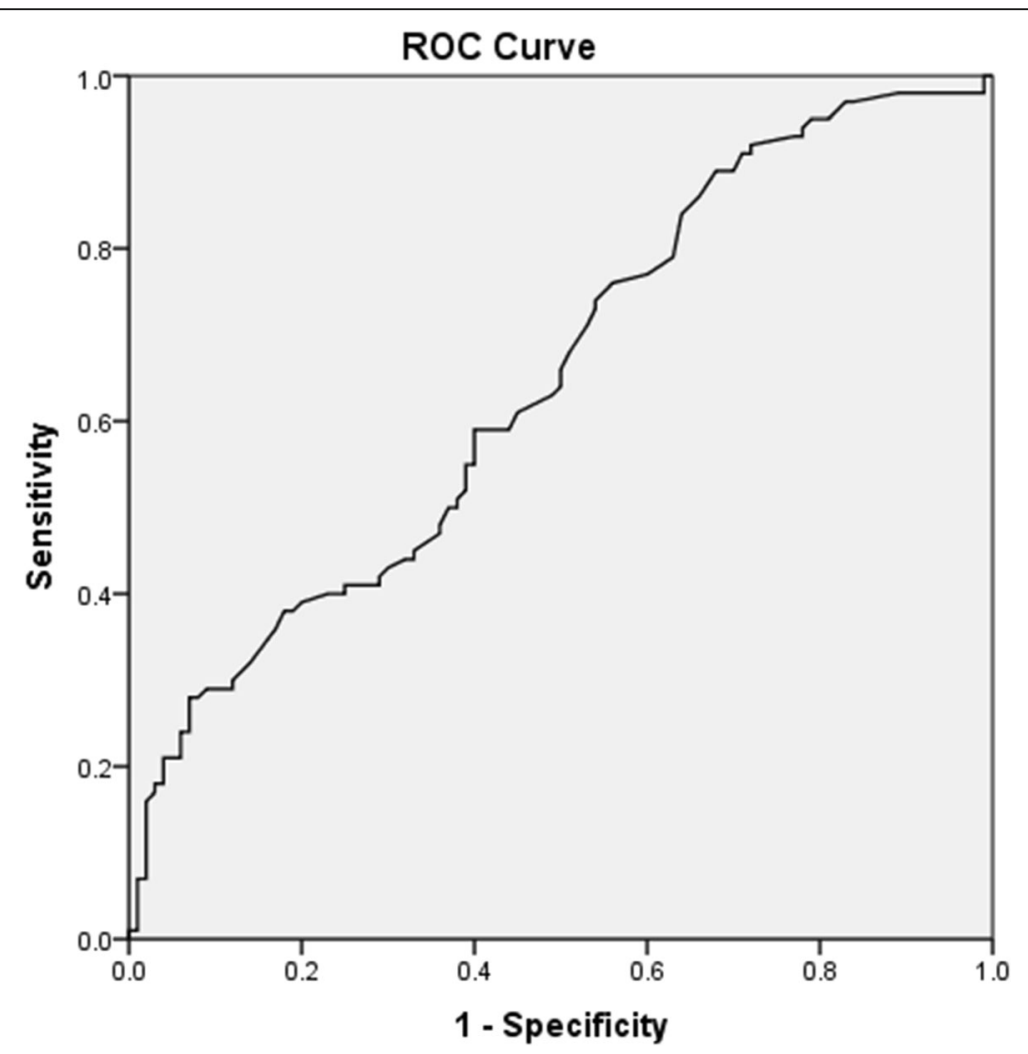

Fig. 3 Roc curve analysis of methylation profile of gene-specific MTHFR. AUC, area under the curve; $95 \% \mathrm{Cl}, 95 \%$ confidence interval 
significant difference observed that needed to be highlighted later on in the "Discussion" section (26.2 \pm 4.7, $27.0 \pm 2.7,48 \%)$ vs. control $(25.7 \pm 5.1,26.4 \pm 2.5$, 36\%); $P$ values: $0.49,0.14,0.08$ (Table 1 ).

The median of percentage of MTHFR promoter methylation in RPL cases was $6.45(0.74-100)$ vs. controls was $4.50(0.60-91.7) ; P$ value $<0.001$ (Table 2). On evaluating roc curve for sensitivity, specificity, and area under the curve, a cutoff value of 5.5 as a threshold for methylation percentage was defined. Among RPL patients, 57 were hypermethylated and 43 were normomethylated vs. 40 hypermethylated and 60 normomethylated among the control group with a significant $P<0.005$ (Table 3).

Analysis for C677T polymorphism was done after methylation quantification to assess if there is a direct correlation between the polymorphism and methylation status in coding region of MTHFR in RPL patients. Accordingly, the frequency of C677T genotype MTHFR gene in RPL patients showed CC genotype 48\%, CT $46 \%$, and TT $6 \%$ vs. control group-CC genotype was $58 \%$, CT $38 \%$, and $\mathrm{TT} 4 \%$ (CC vs. CT: $\mathrm{OR}=1.463$ (0.823-2.600); CC vs.TT: $\mathrm{OR}=1.812(0.483-6.79)$; $\mathrm{CC}$ vs. $\mathrm{CT}+\mathrm{TT}$ : $\mathrm{OR}=1.496(0.856-2.164)$; $\mathrm{CT}+\mathrm{TT}$ vs. TT: $\mathrm{OR}=1.532(0.419-5.603))$. There was no any significant difference in the TT genotype between the two groups. C allele in RPL patients was $71 \%$ vs. $77 \%$ in controls and $\mathrm{T}$ allele was $29 \%$ in RPL patients vs. $23 \%$ in control group. C allele vs. T allele OR: 1.367 (95\% CI $0.725-$ 2.581). Both groups were consistent with Hardy-Weinberg equation 0.242 in RPL patients and 0.466 in control group (Table 4).

On correlating specific methylation percentage with different genotypes among the whole studied population (cases and controls; $n=200$ ), the CC genotype showed significantly lower methylation compared to CT $(p<0.001)$ and TT genotypes $(p=$
0.027). CT and TT genotypes had comparable methylation $(p=1.000)$.

\section{Discussion}

To maintain full-term pregnancy, it is important to have an adequate, controlled internal maternal environment for embryo's growth and development. DNA methylation has a critical role in cellular growth and differentiation of trophoblastic cell lines [15]. The MTHFR gene which is the topic of our study is one of the nonimprinted genes involved in pregnancy loss. Hypermethylation of $\mathrm{CpG}$ islands is typically related with gene silencing. Epigenetic variations are hypothetically changeable. MTHFR gene is a thrombophilic biomarker. It is located at the intersection of reactions generating methyl groups for regulating DNA methylation processes, repair, and synthesis. During gestational period, women go through main physiological and immunological changes mostly affected by methylation patterns of particular accountable genes [16]. MTHFR gene is one of several genes that have a significant role during gestation period by being involved in thrombotic actions or methylation processes. Hypermethylation in the promoter region of MTHFR gene is certain to decrease gene expression which in return lessen accessibility of methyl groups needed in global DNA methylation [10]. In addition, MTHFR C677T polymorphism causes a decrease in enzymatic activity affecting the transmethylation cycle and causing a hypo global DNA methylation due to lack of free methyl groups [11]. The authors aimed by this study to evaluate the methylation status of the promoter region of MTHFR gene in RPL patients in comparison to healthy fertile women.

The authors observed by looking at the results that frequency of methylation in MTHFR promoter region was significantly higher among RPL patients than in controls $(p<0.05)$. We took a step further by doing

Table 1 Descriptive characteristics among RPL patients and controls

\begin{tabular}{|c|c|c|c|c|}
\hline & & Cases $(n=100)$ & Controls $(n=100)$ & $P$ value \\
\hline Age (mean \pm SD) & & $26.2 \pm 4.7$ & $25.7 \pm 5.1$ & 0.49 \\
\hline BMI ( mean \pm SD) & & $27.0 \pm 2.7$ & $26.4 \pm 2.5$ & 0.14 \\
\hline \multirow[t]{2}{*}{ Consanguinity } & Positive & $48 \%$ & $36 \%$ & \\
\hline & Negative & $52 \%$ & $64 \%$ & 0.08 \\
\hline No. abortions & 1 & $4 \pm 1.1$ & NA & \\
\hline \multirow[t]{2}{*}{ Pregnancy loss } & 1st trimester & $28 \%$ & NA & \\
\hline & 2nd trimester & $72 \%$ & & \\
\hline \multirow[t]{4}{*}{ Live births } & 0 & 64 & 0 & \\
\hline & 1 & 35 & 15 & \\
\hline & 2 & 1 & 42 & \\
\hline & 3 & 0 & 43 & \\
\hline
\end{tabular}


Table 2 Methylation among cases of pregnancy loss compared to controls

\begin{tabular}{llll}
\hline & Cases $(\boldsymbol{n}=\mathbf{1 0 0})$ & Controls $(\boldsymbol{n}=\mathbf{1 0 0})$ & $\boldsymbol{P}$ value \\
\hline $\begin{array}{l}\text { Methylation, median (range) } \\
\text { Mann-Whitney } U\end{array}$ & $6.45(0.47-100)$ & $4.50(0.60-91.7)$ & $<0.001$ \\
\hline
\end{tabular}

The $p$ value $<.05$ is significant

receiver operating characteristic (ROC) assessment to find a threshold for methylation level; in this case, it was 5.5. To categorize the participants as either normo- or hypermethylated, ROC curve was plotted displaying true-positive rate (sensitivity) versus false-positive rate (one specificity) and area under the curve (AUC) $=0.647$ and was used to assess how fit the estimate model could discriminate between the two groups (normo- and hypermethylated). We concluded that RPL patients were significantly higher regarding hypermethylation of the MTHFR promoter area compared to control group.

Several authors have strained to comprehend the role of MTHFR C677T polymorphism in correlation with the DNA hypermethylation; nevertheless, scarce studies did not find any association between the frequency of mutant allele and global DNA methylation [17]. According to our results, MTHFR C677T genotypic status of RPL patients in comparison to controls showed that there was an increase in the frequency of the CT and TT genotypes among RPL patients compared to the control group but did not reach statistical significance. Even when combining $\mathrm{CT}+\mathrm{TT}$ genotypes against TT genotype, also no statistical significance was evident between RPL patients and controls. On allele level, $\mathrm{C}$ and $\mathrm{T}$ alleles had comparable frequencies between the two studied groups.

Due to scarcity of literature on MTHFR gene-specific methylation and RPL, the results are not validated with a substantial number of studies. However, comparable results were reached in a previous study which showed that MTHFR genotypic distribution among cases and controls had no significant difference $P=0.409$ [18]. Then, the authors did another study few years later in north India and recruited 85 RPL patients and 121 fertile healthy controls and reported that women carrying methylated allele for MTHFR gene have a significant 3.6-fold increased risk for RPL. The amount risk of methylated allele in RPL women was found to be intensified from the normal genotype CC (2.8 folds) to CT (7.5 folds) individuals [19]. Mishra and his colleagues in

Table 3 Number of hypermethylated and normo-methylated RPL cases vs. number of hypermethylated and normomethylated controls

\begin{tabular}{llll}
\hline & Cases $(\boldsymbol{n}=\mathbf{1 0 0})$ & Controls $(\boldsymbol{n}=\mathbf{1 0 0})$ & $\boldsymbol{P}$ value \\
\hline Hypermethylated & 57 & 40 & 0.016 \\
Normo-methylated & 43 & 60 & \\
\hline
\end{tabular}

The $p$ value $<.05$ is significant
2019 published their study. The results showed that RPL cases were hypermethylated for MTHFR gene in comparison to healthy fertile female in the control group with a statistical significance $p=0.002$. Hypermethylated RPL cases for MTHFR gene were 28 compared to72 agematched controls. But in contrast to our finding, they reported that there was a positive correlation with $\mathrm{C} 677 \mathrm{~T}$ polymorphism. RPL patients carrying CT genotype had a significantly MTHFR gene-specific methylation $p=0.005$ [20]. Study done in Gutenberg University, Germany, had reported a very interesting finding. The study reported the DNA methylation patterns at two paternally methylated (H19 and MEG3) and other four maternally methylated (LIT1, NESP55, PEG3, and SNRPN) imprinted areas among fetus muscle. Samples taken from aborts and stillbirths showed that 2 of 55 (4\%) aborted fetuses and 10 of 57 (18\%) stillbirths exhibited various imprinted genes with a hypermethylated pattern [9]. Furthermore Rotondo and his colleagues [21] reported that there was hypermethylation in promoter region of MTHFR in seminal samples of RPL couples and that CpG islands inside the promoter region were $100 \%$ methylated, i.e., hypermethylation of MTHFR promoter region. The study implicated that these different methylation patterns detected might possibly be related to inadequate maternal uterine environment leading to fetal loss in early pregnancy among RPL patients [21]. Certainly, epigenetic alterations in promoter region and the resulting suppression of gene expression both perform in a similar way and in particular cases equivalent to genetic mutations in certain diseases [22].

Concerning MTHFR C677T polymorphism, a study was done in Egypt involving 70 women with unexplained

Table 4 Frequencies of MTHFR gene polymorphic genotypes and alleles among cases of RPL compared to controls

\begin{tabular}{lllll}
\hline & Patients $(\boldsymbol{n}=\mathbf{1 0 0})$ & Control $(\boldsymbol{n}=\mathbf{1 0 0})$ & OR & $\mathbf{9 5 \% C l}$ \\
\hline CC & $48(48 \%)$ & $58(58 \%)$ & 1 & Ref \\
CT & $46(46.0 \%)$ & $38 \%(38.0 \%)$ & 1.463 & $(0.823-2.600)$ \\
TT & $6(6.0 \%)$ & $4(4.0 \%)$ & 1.812 & $(0.483-6.796)$ \\
CT+TT & $52(52 \% .0)$ & $42(42.0 \%)$ & 1.496 & $(0.856-2.614)$ \\
CC+TT & $94(94 \%)$ & $96(96.0 \%)$ & 1 & \\
TT & $6(6.0 \%)$ & $4(4.0 \%)$ & 1.532 & $(0.419-5.603)$ \\
C & $71(71.0 \%)$ & $77(77.0 \%)$ & 1 & \\
T & $29(29.0 \%)$ & $23(23.0 \%)$ & 1.367 & $(0.725-2.581)$ \\
\hline
\end{tabular}

The $p$ value $<.05$ is significant

$O R$ odds ratio, $\mathrm{Cl}$ confidence intervals 
pregnancy loss and 136 healthy fertile controls stated that MTHFR C677T was not associated with RPL. CT, TT genotypes were increased in cases compared to controls but did not reach statistical significance which was in an agreement with our results [23]. Also other studies concluded that MTHFR C677T was not a predictive risk for recurrent pregnancy loss in different ethnic groups [24-26]. In contrast to our MTHFR PCR-RFLP results, a study performed in Iran involving one hundred and fifty three females revealed that CT and TT for C677T polymorphism were $18.13 \%$ and $13.1 \%$. And all participants who were homozygous for C677T were treated accordingly with anti-coagulant therapy and ended with successful pregnancy [27]. Other studies supported the association of MTHFR C677T polymorphism with RPL as well $[28,29]$.

This raised our attention to a question: what could be the possible other epigenetic causes that might lead to hypermethylation in promoter region of MTHFR gene among women suffering from RPL irrespective to $M T H F$ $R$ C677T polymorphism. We believe that in cases of RPL especially (unexplained RPL), early finding of new prognostic marker as DNA hypermethylation would be of great help to obstetricians for early detection of RPL cases. There are several theories correlating hypermethylation status found among the DNA of patients with unexplained recurrent pregnancy loss. It is proposed that hypermethylation status of MTHFR promoter region found among RPL patients favor the direction of epigenetic silencing, leading to a decreased accessibility of methyl groups needed in the epigenetic processes which is crucial for normal fetal development and results in pregnancy loss [19]. Other theory is how the immune system might have different response regarding the acceptance and accommodation of the fetus. Because hereditary spontaneous modifications in DNA methylation have a significant roles in the normal function process of the immune system, for instance in T-cell biology [30]. Changes in DNA methyltransferase (DMT )and teneleven translocation( TET) enzyme levels have a role in fluctuation of DNA methylation status as well as hydroxymethylation process [31]. La Rocca and his colleagues [32] done a study which supports this point of view. Epigenetic profile of the genome is reprogrammed dynamically during the early development of the fetus [19].

Also taking insights among surrounding environmental factors especially in our country for example environmental maternal exposure to extreme life events (pollution, excessive passive smoking, heavy load work, lack of healthy diet) especially among low socioeconomic class women earlier or throughout the time of conception may be related with changes in the normal epigenetic mechanisms. Epigenetic mechanisms are believed to arbitrate environmental effects on gene regulation and to moderate susceptibility to certain diseases [33, 34]. Though pregnancy loss is considered to be a psychological letdown because of the loss of the fetus but looking at it from the another point of view, it may be considered fortunate as the abnormal epigenetic load from the maternal side gets lost and not transferred to the next generation. Our study is limited by the fact that we could not analyze fetal tissue as well; results would have been more valid and interesting after comparison of feto-maternal methylation patterns and that it was difficult to collect adequate controls.

\section{Conclusion}

There is a correlation between methylation statuses of MTHFR coding region with RPL. This differential methylation pattern observed among RPL cases could possibly be responsible for the inadequate maternal uterine environment. This study highlights the significance of epigenetic mechanisms in pregnancy loss. As methylation process plays an essential role in the fetus programming and the expected wellbeing of the offspring. Recognition of abnormal methylation levels early during gestation period might help in early detection RPL cases. This study is a primarily step for other researches to be done on the topic but preverbal on larger sample size studies before making any solid conclusions and additionally offers a new vision in recognizing the underlying epigenetic markers triggering RPL.

\section{Abbreviations \\ AUC: Area under the curve; BMl: Body mass index; Cl: Confidence interval; CpG: Cytosine-phosphate-guanine; DMT: DNA methyltransferase; EDTA: Ethylenediaminetetraacetic acid; MTHFR: Methylenetetrahydrofolate reductase; OR: Odds ratio; RFLP: Restriction fragment length polymerase; RPL: Recurrent pregnancy loss; ROC: Receiver operating characteristic; TET: Ten-eleven translocation}

\section{Acknowledgements}

Not applicable

\section{Authors' contributions}

MS performed the molecular work up and wrote the manuscript. TS set the study design, prenatal counseling, and clinical evaluation of the participants. $\mathrm{KA}$ analyzed and interpreted the results and revised the final manuscript. All authors read and approved the final manuscript.

\section{Funding}

This research did not receive any specific grant from funding agencies in the public, commercial, or not-for-profit sectors.

\section{Availability of data and materials}

The datasets generated and/or analyzed during the current study are not publicly available due to patient's privacy but are available from the corresponding author on reasonable request.

\section{Declarations}

Ethics approval and consent to participate

This study was approved by the ethics committee (Medical Research Ethics Committee of National research center, Cairo, Egypt) with approval number (19266).The participants provided written consent. 


\section{Consent for publication}

Not applicable.

\section{Competing interests}

The authors declare that they have no competing interests.

\section{Author details}

'Prenatal and Fetal Medicine Department, Human Genetics and Genome Research Division, National Research Centre, 33 El Buhooth St, Dokki, Cairo, Egypt. ${ }^{2}$ Medical Molecular Genetics Department, Human Genetics and Genome Research Division, National Research Centre, 33 El Buhooth St, Dokki, Cairo, Egypt.

Received: 12 January 2021 Accepted: 12 March 2021

\section{Published online: 22 March 2021}

\section{References}

1. Jadavji NM, Wieske F, Dirnagl U, Winter C (2015) Methylenetetrahydrofolate reductase deficiency alters levels of glutamate and $y$-aminobutyric acid in brain tissue. Mol Genet Metab Reports 3:1-4. https://doi.org/10.1016/j. ymgmr.2015.02.001

2. Novakovic B, Rakyan V, Ng HK, Manuelpillai U, Dewi C, Wong NC, Morley R, Down T, Beck S, Craig JM, Saffery R (2008) Specific tumour-associated methylation in normal human term placenta and first-trimester cytotrophoblasts. Mol Hum Reprod 14(9):547-554. https://doi.org/10.1093/ molehr/gan046

3. Tanaka S, Nakanishi MO, Shiota K (2014) DNA methylation and its role in the trophoblast cell lineage. Int J Dev Biol 58(2-3-4):231-238. https://doi.org/1 $0.1387 / \mathrm{ijdb} .140053 \mathrm{st}$

4. Sinclair KD, Singh R (2007) Modelling the developmental origins of health and disease in the early embryo. Theriogenology 67(1):43-53. https://doi. org/10.1016/j.theriogenology.2006.09.017

5. Messerschmidt DM, Knowles BB, Solter D (2014) DNA methylation dynamics during epigenetic reprogramming in the germline and preimplantation embryos. Genes Dev 28(8):812-828. https://doi.org/10.1101/gad.234294.113

6. Wu W, Shen O, Qin Y, Niu X, Lu C, Xia Y, Song L, Wang S, Wang X (2010) Idiopathic male infertility is strongly associated with aberrant promoter methylation of methylenetetrahydrofolate reductase (MTHFR). PLoS One 5(11):e13884. https://doi.org/10.1371/journal.pone.0013884

7. Biermann K, Steger K (2007) Epigenetics in male germ cells. J Androl 28(4): 466-480. https://doi.org/10.2164/jandrol.106.002048

8. Lucas ES, Dyer NP, Murakami K, Hou Lee Y, Chan YW, Grimaldi G, Muter J, Brighton PJ, Moore JD, Patel G, Chan JKY, Takeda S, Lam EWF, Quenby S, Ott S, Brosens JJ (2016) Loss of endometrial plasticity in recurrent pregnancy loss. Stem Cells 34(2):346-356. https://doi.org/10.1002/stem.2222

9. Pliushch G, Schneider E, Weise D, El Hajj N, Tresch A, Seidmann L et al (2010) Extreme methylation values of imprinted genes in human abortions and stillbirths. Am J Pathol 176(3):1084-1090. https://doi.org/10.2353/ajpa th. 2010.090764

10. Dos Santos Nunes MK, Silva AS, De Queiroga Evangelista IW, Filho JM, Gomes CNAP, Do Nascimento RAF et al (2017) Hypermethylation in the promoter of the MTHFR gene is associated with diabetic complications and biochemical indicators. Diabetol Metab Syndr 9(1). https://doi.org/10.1186/ s13098-017-0284-3

11. Ozdemir O, Silan F, Urfali M, Uludag A, Ari E, Kayatas M. Variable R.Msp1 fragmentation in genomic DNA due to DNA hypomethylation in CRF patients with MTHFR C677Tgene polymorphism: From genetics to epigenetics. Gene Ther Mol Biol 2014.

12. Miller SA, Dykes DD, Polesky HF (1988) A simple salting out procedure for extracting DNA from human nucleated cells. Nucleic Acids Res 16(3):1215. https://doi.org/10.1093/nar/16.3.1215

13. Antonaros F, Olivucci G, Cicchini E, Ramacieri G, Pelleri MC, Vitale L, Strippoli P, Locatelli C, Cocchi G, Piovesan A, Caracausi M (2019) MTHFR C677T polymorphism analysis: a simple, effective restriction enzyme-based method improving previous protocols. Mol Genet Genomic Med 7(5):e628. https:// doi.org/10.1002/mgg3.628

14. Ng EKO, Leung CPH, Shin WY, Wong CLP, Ma ESK, Jin HC, Chu KM, Kwong A (2011) Quantitative analysis and diagnostic significance of methylated SLC19A3 DNA in the plasma of breast and gastric cancer patients. PLoS One 6(7):e22233. https://doi.org/10.1371/journal.pone.0022233
15. Khot W, Yadav DK, Shrestha S, Kaur L, Sundrani DP, Chavan-Gautam PM, Mehendale SS, Chandak GR, Joshi SR (2017) Hypermethylated CpG sites in the MTR gene promoter in preterm placenta. Epigenomics 9(7):985-996. https://doi.org/10.2217/epi-2016-0173

16. Van Mil NH, Bouwl-Both MI, Stolk L, Verbiest MMPJ, Hofman A, Jaddoe WW et al (2014) Determinants of maternal pregnancy one-carbon metabolism and newborn human DNA methylation profiles. Reproduction 148(6):581592. https://doi.org/10.1530/REP-14-0260

17. Hanks J, Ayed I, Kukreja N, Rogers C, Harris J, Gheorghiu A, Liu CL, Emery P, Pufulete M (2013) The association between mthfr 677C>T genotype and folate status and genomic and gene-Specific dna methylation in the colon of individuals without colorectal neoplasia1-4. Am J Clin Nutr 98(6):15641574. https://doi.org/10.3945/ajcn.113.061432

18. Puri M, Kaur L, Walia GK, Mukhopadhhyay R, Sachdeva MP, Trivedi SS, Ghosh PK, Saraswathy KN (2013) MTHFR C677T polymorphism, folate, vitamin B12 and homocysteine in recurrent pregnancy losses: A case control study among north Indian women. J Perinat Med 0(0):1-6. https://doi.org/10.151 5/.jpm-2012-0252

19. Saraswathy K, Kaur L, Talwar S, Mishra J, Huidrom S, Sachdeva M, Puri M (2018) Methylenetetrahydrofolate reductase gene-specific methylation and recurrent miscarriages: A Case-Control Study from North India. J Hum Reprod Sci 11(2):142-147. https://doi.org/10.4103/jhrs.JHRS_145_17

20. Mishra J, Talwar S, Kaur L, Chandiok K, Yadav S, Puri M, Sachdeva MP, Lakshmy R, Saraswathy KN (2019) Differential global and MTHFR gene specific methylation patterns in preeclampsia and recurrent miscarriages: A case-control study from North India. Gene 704:68-73. https://doi.org/10.101 6/j.gene.2019.04.036

21. Rotondo JC, Bosi S, Bazzan E, Di Domenico M, De Mattei M, Selvatici R et al (2012) Methylenetetrahydrofolate reductase gene promoter hypermethylation in semen samples of infertile couples correlates with recurrent spontaneous abortion. Hum Reprod 27(12):3632-3638. https://doi. org/10.1093/humrep/des319

22. Baylin SB, Herman JG (2000) DNA hypermethylation in tumorigenesis: Epigenetics joins genetics. Trends Genet 16(4):168-174. https://doi.org/10.1 016/S0168-9525(99)01971-X

23. Settin A, Elshazli R, Salama A, Elbaz R (2011) Methylenetetrahydrofolate reductase gene polymorphisms in egyptian women with unexplained recurrent pregnancy loss. Genet Test Mol Biomarkers 15(12):887-892. https://doi.org/10.1089/gtmb.2011.0049

24. Khan R (2019) Association of MTHFR C677T with Idiopathic Recurrent Pregnancy Loss in Anhui Province of China. Int J Hum Genet 19(04). https:// doi.org/10.31901/24566330.2019/19.04.01

25. Hwang KR, Choi YM, Kim JJ, Lee SK, Yang KM, Paik EC, Jeong HJ, Jun JK, Yoon SH, Hong MA (2017) Methylenetetrahydrofolate reductase polymorphisms and risk of recurrent pregnancy loss: a case-control study. J Korean Med Sci 32(12):2029-2034. https://doi.org/10.3346/jkms.2 017.32.12.2029

26. Babker AMAAA, Gameel FEMH (2016) Methylenetetrahydrofolate reductase C677T polymorphism in sudanese women with recurrent spontaneous abortions. Kuwait Med J

27. Keyfi F, Ebrahimzadeh-Vesal R, Zhiyan N, Nayebi M, Nasseri M, Abbaszadegan MR (2018) The relationship between MTHFR polymorphisms and abortion in Iranian women. Gene Reports 13:130-133. https://doi.org/1 0.1016/j.genrep.2018.09.008

28. Mohammed SS, Al-Timimy RA, Hassan JN, Mahmood NT (2018) Association of The Mthfr C677t, Factor V (Leiden) G1961a and Prothrombin G20210a Gene Mutations with Recurrent Spontaneous Aboration (Rsa) in Duhok Province. Sci J Univ Zakho 6(3):85-88. https:// doi.org/10.25271/sjuoz.2018.6.3.509

29. Zarfeshan Fard Y, Kooshkaki O, Kordi Tammandani D, Anani SG (2019) Investigation of the association between C677T polymorphism of the MTHF $\mathrm{R}$ gene and plasma homocysteine level in recurrent fetal miscarriage. J Obstet Gynaecol Res 45(8):1442-1447. https://doi.org/10.1111/jog.13989

30. Schmidl C, Delacher M, Huehn J, Feuerer M (2018) Epigenetic mechanisms regulating T-cell responses. J Allergy Clin Immunol 142(3):728-743. https:// doi.org/10.1016/j.jaci.2018.07.014

31. Álvarez-Errico D, Vento-Tormo R, Ballestar E (2017) Genetic and epigenetic determinants in autoinflammatory diseases. Front Immunol 8. https://doi. org/10.3389/fimmu.2017.00318

32. La Rocca C, Carbone F, Longobardi S, Matarese G (2014) The immunology of pregnancy: regulatory $T$ cells control maternal immune 
tolerance toward the fetus. Immunol Lett 162(1):41-48. https://doi.org/1 0.1016/j.imlet.2014.06.013

33. Foley DL, Craig JM, Morley R, Olsson CJ, Dwyer T, Smith K, Saffery R (2009)

Prospects for epigenetic epidemiology. Am J Epidemiol 169(4):389-400.

https://doi.org/10.1093/aje/kwn380

34. Feinberg AP (2007) Phenotypic plasticity and the epigenetics of human disease. Nature 447(7143):433-440. https://doi.org/10.1038/nature05919

\section{Publisher's Note}

Springer Nature remains neutral with regard to jurisdictional claims in published maps and institutional affiliations.

Submit your manuscript to a SpringerOpen ${ }^{\mathcal{O}}$ journal and benefit from:

- Convenient online submission

Rigorous peer review

- Open access: articles freely available online

- High visibility within the field

- Retaining the copyright to your article

Submit your next manuscript at $\boldsymbol{\sim}$ springeropen.com 